Cornell Law Library

Scholarship@Cornell Law: A Digital Repository

Cornell Law Faculty Working Papers

Faculty Scholarship

$1-14-2013$

\title{
Anti-competitive Agreements: The Meaning of "Agreement"
}

George A. Hay

Cornell Law School, george.hay@cornell.edu

Follow this and additional works at: http://scholarship.law.cornell.edu/clsops_papers

Part of the Antitrust and Trade Regulation Commons

\section{Recommended Citation}

Hay, George A., "Anti-competitive Agreements: The Meaning of "Agreement"" (2013). Cornell Law Faculty Working Papers. Paper 105. http://scholarship.law.cornell.edu/clsops_papers/105

This Book Chapter is brought to you for free and open access by the Faculty Scholarship at Scholarship@Cornell Law: A Digital Repository. It has been accepted for inclusion in Cornell Law Faculty Working Papers by an authorized administrator of Scholarship@Cornell Law: A Digital Repository. For more information, please contact jmp8@cornell.edu. 
Anti-competitive Agreements: the meaning of "agreement"

By

George A. Hay*

* Edward Cornell Professor of Law and Professor of Economics, Cornell University, Ithaca, NY USA. The author is grateful to several Cornell Law School students, especially Colin McKeon and Briana Serano, for assistance in preparing this chapter. 


\section{Introduction}

In the classic cartel, supposed competitors meet in the proverbial smoke-filled hotel room and agree to fix prices at supra-competitive levels. (For convenience, these will be referred to as monopoly prices, despite the fact that a cartel may not always agree on the same price as a single firm that controlled $100 \%$ of the market would charge.) Even though the "agreement" is unlikely to be legally binding on the parties (i.e., the agreement could not be enforced against one of the cartelists that began to "cheat" by offering lower prices), virtually all modern economies would treat such a cartel as unlawful under their national antitrust laws. For the United States, this negative attitude toward cartels is both long-standing (dating virtually to the passage of the Sherman Act in 1890) and harsh, with the potential not only for very large fines (in 2012, the Department of Justice sought a fine of $\$ 1$ billion just for one of several participants in the LCD cartel - AU Optronics - and the court granted a fine of $\$ 500$ million ) but also for incarceration for key individual participants (the DOJ asked for 10 year prison sentences for two individual executives of AUO and the court awarded three-year sentences). ${ }^{1}$ And, of course, there is the very real possibility of follow-on private actions seeking damages that are automatically trebled. A recent report indicated that the total of the settlements reached thus far on behalf of U.S. consumers with members of the LCD cartel was $\$ 1.1$ billion. $^{2}$

Other jurisdictions have come more recently to treat cartels harshly, but prosecution of such cartels is now pursued vigorously on a global scale. Outside the U.S., the imposition of large fines is now commonplace, in part because, unlike the U.S., in many jurisdictions, such as the European Union, a fine is not regarded as a "criminal" penalty. The EU recently leveled a fine of

\footnotetext{
${ }^{1}$ See Press Release, U.S. Dep't of Justice, Taiwan-Based AU Optronics Corporation Sentenced to Pay $\$ 500$ Million Criminal Fine for Role in LCD Price-Fixing Conspiracy (Sept. 20, 2012) (available at http://www.justice.gov/atr/public/press releases/2012/287189.htm).

${ }^{2}$ Stephanie Mlot, Buy an LCD? Sign Up for Piece of \$1.1B Price-Fixing Deal, PCMAG.com (Oct. 23, 2012, 11:19 AM), http://www.pcmag.com/article2/0,2817,2411290,00.asp.
} 
$€ 1.47$ bilion (U.S. $\$ 1.92$ billion) on participants in a cathode-ray tube cartel. ${ }^{3}$ Prison sentences for involved individuals are far less common, but a number of jurisdictions, including Australia, for example, have moved to criminalize cartel behavior and thereby hold out the possibility of incarceration, and there is likely to be further movement in that direction. ${ }^{4}$ Private damage actions are not as prevalent outside the U.S. for a variety of reasons, including the lack of a trebling provision in the relevant statute and the difficulty of effectively maintaining a class action, but even here there seems to be some movement toward the U.S. model. ${ }^{5}$

In sum, while the penalties for the cartels that are detected and prosecuted differ across jurisdictions, the basic attitude that such "garden-variety" cartels are and should be unlawful is remarkably consistent. Moreover, the ability to detect (and therefore prosecute) such cartels has evolved rapidly over the past twenty or so years, in part because of a remarkable degree cooperation among enforcement authorities around the world, but in even larger part because of the effectiveness of various leniency programs maintained by multiple jurisdictions around the world (the U.S. and the E.U. being the most notable examples) that offer some diminution in adverse consequences for the first member of a cartel to come forward, confess its own role,

\footnotetext{
${ }^{3}$ Lucian Constantin, EU fines CRT makers $€ 1.47$ billion for price-fixing, PC ADVISOR (Dec. 05, 2012), http://www.pcadvisor.co.uk/news/digital-home/3414922/eu-fines-crt-makers-147-billion-for-pricefixing/\#ixzz2EC2A1Qyg.

${ }^{4}$ See, e.g., Caron Beaton-Wells, Australia's criminalization of cartels: Will it be contagious?, in MORE COMMON GROUND FOR COMPETITION LAW? 148-73 (Josef Drexl et al. eds., 2011).

${ }^{5}$ See, e.g., Tiana Leia Russell, Exporting Class Actions to the European Union, 28 B.U. INT'L L.J. 141 (2010)

(discussing, among other developments, "recent calls within the European Union for greater private enforcement of competition law and [outlining] steps the European Commission has taken to address that need, including the recently published White Paper on Damages for Breach of EC Antitrust Rules."). European Competition Commissioner Almunia announced that he intends to submit to the College of Commissioners a legislative proposal on private antitrust damage actions that would, among other things, make it easier for victims of cartels to gain access to evidence uncovered by the Commission. See Joaquin Almunia, Vice President of the European Comm'n Responsible for Competition Policy, The Role of Competition Policy in Times of Crisis, Address Before the 29th Annual AmCham EU Competition Policy Conference (Dec. 6, 2012) (transcript available at http://europa.eu/rapid/press-release_SPEECH-12917_en.htm).
} 
and provide evidence implicating other members of the cartel. ${ }^{6}$ Indeed, the frequency of new cartel discoveries that are reported around the world in various antitrust newsletters suggest that cartelists are almost tripping over themselves in a rush to be the first to confess.

Yet the suspicion remains that, despite the effectiveness of the leniency programs in encouraging confessions, there are still cartels (both domestic and international) that operate under a cloak of secrecy, and therefore governments must continue to use more conventional tools to seek them out and prosecute them. Sometimes these traditional investigatory tools will yield the confession or the hot documents that will make prosecution easy, but not always. So the question arises: in the absence of a video-taped cartel meeting, a cooperating participant, or incriminating documents, can a cartel be successfully prosecuted based primarily on "circumstantial" evidence?

However, it is not just a question of what kind of circumstantial evidence can be used to establish the existence of a hard-core cartel - that question might best be described in these circumstances as akin to an economic detective story. A more complicated substantive question underlies the effort to describe the type and quantity of the circumstantial evidence necessary to obtain a successful prosecution, namely, what precisely do we mean to include under the category of an illegal "agreement" or "conspiracy" or "concerted practice?"

The contract lawyer's reaction to such a question might be one of puzzlement as it why it is being asked. After all, every good contract lawyer is trained to identify when parties have reached an "agreement." But not so fast. The contract lawyer's assignment is to determine when the parties have reached an agreement that can be enforced in court against those who

\footnotetext{
${ }^{6}$ Details of the Department of Justice's Antitrust Leniency Program are provided on the Antitrust Division's website at http://www.justice.gov/atr/public/criminal/leniency.html. Details of the EU Leniency Program can be found on the EU website at http://ec.europa.eu/competition/cartels/legislation/leniency legislation.html.
} 
attempt to violate its terms. But we already know that, in almost all jurisdictions, the "gardenvariety" cartel, as described above, does not produce a legally binding agreement. In almost any jurisdiction, any such "agreement" would be void and unenforceable as against public policy. So the cartels we are most interested in prosecuting are not cartels that have reached "agreement" in the technical legal sense. And if the antitrust "agreement" is different from and in some ways less than the contract lawyer's agreement, then we need to establish exactly what counts as an agreement or conspiracy or concerted practice (depending on the language of the relevant statute) in order to know how to prove its existence. In other words, to know how to establish the existence of an unlawful agreement under the antitrust laws, we must first develop a sense of what "counts" as an unlawful agreement and how far our concept of an unlawful agreement can depart from the contract lawyer's notion of a legally binding contract. ${ }^{7}$

The plan of this chapter is to begin by describing how the U.S. treats classic cartel behavior when proof of the existence of a cartel agreement is not an issue. Then we turn to the task of establishing the existence of an illegal agreement primarily or entirely through circumstantial evidence. This will quickly get us into the question of what constitutes an unlawful agreement under U.S. law and in particular, the recently renewed debate about whether classic oligopoly behavior can be prosecuted as an unlawful agreement. In the process, we will refer to how similar issues are dealt with in other jurisdictions, most notably the European Union.

\section{Antitrust Treatment of "Hard-Core" Cartels}

\footnotetext{
${ }^{7}$ To be more concrete, if the only kind of "agreement" that the Sherman Act recognized were to be one in which there were direct, face-to-face communication, as in the classic smoke-filled room, that would have significant implications for the kind of circumstantial evidence that might support a finding of agreement. At the opposite end of the spectrum, if the law treated simple oligopolistic interdependence as also constituting an agreement, the range of relevant circumstantial evidence would be much wider.
} 
Section 1 of the Sherman Act prohibits every "contract, combination ... or conspiracy, in restraint of trade or commerce..." It is rare for courts to assign separate meanings to the three categories of offense, and so the statute is usually paraphrased as prohibiting any "agreement" in restraint of trade. In the EU, Article 101 prohibits "all agreements between undertakings, decisions by associations of undertakings and concerted practices" which directly or indirectly fix prices. More than a century ago, U.S. courts determined that price-fixing, as represented by the classic cartel, belonged in the prohibited category, ${ }^{8}$ and that such cartel agreements fixing prices could not be defended on the ground that they were "reasonable."” The phrase "illegal per se" was formally added to the antitrust lexicon involving price fixing in 1940 , when the Supreme Court declared that "a combination formed for the purpose and with the effect of raising, depressing, fixing, pegging, or stabilizing the price of a commodity in interstate or foreign commerce is illegal per se." ${ }^{10}$ While the EU has not specifically adopted the "per se" designation for traditional price fixing, the practical effect is the same. ${ }^{11}$

With the per se rule firmly established for classic cartels, the Court turned its attention to questions of whether the rule would apply to all kinds of defendants in all kinds of circumstances. In Goldfarb the Court made it clear that the per se rule against price fixing applied to professions, such as lawyers, though in a famous footnote the Court decreed that other kinds of agreements that would merit per se treatment for traditional commercial entities, such as an agreement not to engage in certain kinds of advertising, for example, might be evaluated under the rule of reason if the restraint could be characterized as an ethical norm

\footnotetext{
${ }^{8}$ United States v. Addyston Pipe \& Steel Co., 85 F. 271, 293 (6th Cir. 1898), aff'd, 175 U.S. 211 (1899).

${ }^{9}$ The classic "reasonableness defense" had one or more of the following elements: a) the cartel does not have the power to impose unreasonable prices; $b$ ) the cartel had a reasonable purpose (i.e., a purpose other than to impose unreasonable prices); c) the actual prices agreed to were not unreasonable.

${ }^{10}$ United States v. Socony-Vacuum Oil Co., 310 U.S. 150, 223 (1940).

${ }^{11}$ See, e.g., Antitrust Overview, EUROPEAN COMmISsION, http://ec.europa.eu/competition/antitrust/overview en.html (last updated Aug. 13, 2012).
} 
aimed at regulating and thereby promoting competition. ${ }^{12}$ In 1979 in Broadcast Music (BMI), the Court determined that a rule of reason analysis should be applied where the price fixing was ancillary to the establishment of a joint venture that created a new product. ${ }^{13}$ In 1984 , the Court found the NCAA liable for what it characterized as price fixing although the Court modified its analysis to take a "quick Look" at the NCAA's alleged procompetitive justification on the grounds that the NCAA was a "league" and that in the context of a league, some horizontal agreements are necessary for the league to function. The quick look was very quick, however, as the Court found no basis for the NCAA's claim that the price fixing was necessary for the league to function.

Therefore, while there are circumstances where the per se rule may not apply to price fixing, these tend to be quite limited and generally involve some sort of (legitimate) joint venture where the price fixing is seen as at least facially ancillary to the functioning of the joint venture. ${ }^{14}$ As applied to the "garden-variety" cartel, however, the per se rule seems firmly established. $^{15}$

\section{Proving the Existence of a Cartel Agreement}

\footnotetext{
${ }^{12}$ Goldfarb v. Va. State Bar, 421 U.S. 773, 778 n.17 (1975). Almost immediately thereafter, the Court made it clear that switching to a rule of reason analysis did not open up every possible defense argument and that the only inquiry under the rule of reason would be whether the restrictive agreement on balance promoted or restricted competition. Nat'I Soc'y of Prof'I Engineers v. United States, 435 U.S. 679, 696 (1978).

${ }^{13}$ Broad. Music, Inc. v. Columbia Broad. Sys., 441 U.S. 1, 24 (1979). While the BMI opinion contained language that may have suggested a much more substantial narrowing of the reach of the per se rule, the Court in 1982 seemed to reaffirm its commitment to the rule when price fixing occurred outside the context of a joint venture in holding that it applied even to an agreement setting maximum prices. Arizona v. Maricopa Cnty. Medical Soc'y, 457 U.S. 332, 348 (1982).

${ }^{14}$ Where a court finds in its "quick look" that the price fixing is not genuinely ancillary to the functioning of the joint venture, it essentially reverts to per se analysis.

${ }^{15}$ The most interesting "relaxation" of the rule was by an appellate court which held that agreements on financial aid by Ivy League and other colleges were properly characterized as price fixing but should nevertheless be assessed under the rule of reason because the schools were non-profit entities without a profit-maximizing purpose. Moreover, the court directed the trial court (on remand) to take into account the social welfare justifications as a possible offset to the anticompetitive effect. The case then settled. United States v. Brown Univ., 5 F.3d 658, 678 (3d Cir. 1993).
} 
Of course, while the per se rule gives the plaintiff a great litigating advantage once the existence of a cartel agreement is established, there is still the task of establishing the existence of the cartel agreement in the first place. In an ideal plaintiff's world, that task would be facilitated by the existence of one or more kinds of "hard" evidence, such as a videotape of the cartel meeting ${ }^{16}$ confession and cooperation by a key participant in the cartel meetings, or an incriminating document that can be described as a "smoking gun." Confessions have been a frequent source of evidence in the last 10 or so years, as the U.S. and other jurisdictions have introduced amnesty programs for the first participant in a cartel to come forward with a confession and a promise of cooperation aimed at implicating other participants. ${ }^{17}$ To date, there is no formal reward program for whistleblowers (such as that employed by the Internal Revenue Service to detect tax evasion, or by the SEC under Dodd-Frank to uncover securities fraud) but one suspects that a statute creating such a program is not too far off.

But what happens when there is no "hard" evidence (or at least not enough by itself to ensure successful prosecution)? Can the plaintiff win a price-fixing case when the only evidence is circumstantial? And if the answer to that question is "yes," what exactly is the nature of the evidence that a court will entertain and find persuasive? Or perhaps more critically, since most

\footnotetext{
${ }^{16}$ This is rare but not impossible. In the case of the worldwide lysine cartel, the Justice Department persuaded a cooperating witness to arrange for a cartel meeting to be help in the U.S. at a resort hotel (with the incentive being a very nice golf course on the premises for post-meeting enjoyment). The meeting room was equipped with a secret camera and microphone, so the entire proceedings were videotaped. See Scott D. Hammond, U.S. Dep't of Justice Antitrust Div. Deputy Assistant Attorney General, Caught in the Act: Inside an International Cartel, Address Before OECD Competition Committee (Oct. 18, 2005) (transcript available at http://www.justice.gov/atr/public/speeches/212266.pdf). Highlights of the full recording were distributed on request by the Justice Department. Id. at n.1. ("Copies of the tape and transcripts are available at no charge by mailing ... your request to the United States Department of Justice, Antitrust Division, Freedom of Information Act Unit, 325 Seventh Street, NW, Suite 200, Washington, D.C., 20530.").

${ }^{17}$ See Scott D. Hammond, U.S. Dep't of Justice Antitrust Div. Director of Criminal Enforcement, Cornerstones of an Effective Leniency Program, Address Before ICN Workshop On Leniency Programs (Nov. 22-23, 2004) (transcript available at http://www.justice.gov/atr/public/speeches/206611.pdf). For an overview of the EU leniency policy, see Cartels: Leniency, EUROPEAN COMMISSION, http://ec.europa.eu/competition/cartels/leniency/leniency.html (last updated Apr. 16, 2012).
} 
cartel cases in the U.S., if they are litigated to a conclusion, will be decided by a lay jury, ${ }^{18}$ what evidence is sufficient to allow the case to go to the jury? ${ }^{19}$

\section{Use of Circumstantial Evidence}

A general framework for answering these questions was provided by the Court in the classic Interstate Circuit case from $1939 .{ }^{20}$ Interstate Circuit was a chain of so-called "first-run" movie theaters and had a dominant share of the first-run theaters in the relevant geographic market. ${ }^{21}$ Despite its "monopoly," Interstate was concerned about competition from "second-run" theaters that did not have the latest releases but charged lower admission prices. Interstate

${ }^{18}$ In criminal cases, the defendant is entitled to a jury. In private treble damage cases, if the amount in question is greater that a de minimis threshold, either party can ask for a lay jury. Typically it is the plaintiff who requests the jury, presumably out of a perception, not necessarily supported by empirical data, that juries will be more favorable to plaintiffs than judges in price fixing cases. See, e.g., Kevin M. Clermont \& Theodore Eisenberg, Trial by Jury or Judge: Transcending Empiricism, 77 CORNELL L. REV. 1124 (1992).

${ }^{19}$ The defendant has various opportunities to ask the judge to dismiss the case either before a jury has begun to deliberate or even after a jury has announced its verdict. While there are occasional permutations the basic scheme is as follows. After the complaint has been filed but before broad discovery has commenced (there may be some limited and finely tailored discovery on a specific issue), the defendant can move to dismiss the complaint. This kind of dismissal used to be quite rare in the absence of an incompetently drafted complaint, but in the wake of Twombly, such dismissals are not uncommon. See Bell Atlantic Corp. v. Twombly, 550 U.S. 544 (2007). See also, Kevin M. Clermont, Inventing Tests, Destabilizing Systems, 95 IOWA L. ReV. 821 (2010); Colleen McMahon, The Law of Unintended Consequences: Shockwaves in the Lower Courts After Bell Atlantic Corp. v. Twombly, 41 SUFFOLK U. L. REV. 851 (2008). Before the formal courtroom trial begins but after a lot of evidence in the form of documents and oral depositions has been amassed, a defendant can seek summary judgment on the grounds that there is no relevant dispute about the facts so that the only issues are legal. Once the courtroom trial has concluded, either just before the case is turned over to the jury or right after the jury has reached a verdict, the defendant can seek judgment as a matter of law (formerly called, respectively, a motion for directed verdict or a motion for judgment notwithstanding the verdict (JNOV)). Since juries do not publish opinions, virtually all of the significant "law" involving cartels and circumstantial evidence comes in response to one of these motions.

${ }^{20}$ Interstate Circuit, Inc. v. United States, 306 U.S. 208 (1939).

${ }^{21}$ First-run theaters were a critical part of the movie business before the emergence of television advertising of newly released films. Today, the latest blockbuster-to-be is released simultaneously in many theaters in all major metropolitan areas, accompanied by massive television advertising to generate demand to see the film. But back before television, a film would be released very selectively - typically in only a single theater (the first-run theater) in most markets and demand would be created by word-ofmouth from those who saw the film in the first weeks or months. Only much later would it be released more widely. For some history of this and other practices, see MICHAEL CONANT, ANTITRUST IN THE MOTION PICTURE INDUSTRY: ECONOMIC AND LEGAL ANALYSIS (1960). 
persuaded each of the eight major movie distributors, as a condition of being able to access Interstate's first-run theaters, to impose onerous licensing terms on the second-run theaters that would result in their charging higher prices and otherwise limiting their competitiveness. At the time, it was not certain that the eight individual agreements, each involving Interstate and one distributor, would be found to be unlawful, so the Justice Department alleged that the eight distributors had agreed among themselves to go along with Interstate's demands and effectively increase prices to the second-run theaters. The case went to the Supreme Court primarily on the issue of whether there was evidence to support the trial court's conclusion that the eight had agreed among themselves.

The Court, in upholding the trial court's finding of a horizontal agreement, emphasized two related aspects of the emergence of the eight essentially identical agreements between Interstate and each of the distributors. The first was that the new contracts represented a "radical departure" from the previous arrangements between Interstate and the distributors and the distributors and the second-run theaters. ${ }^{22}$ Just like a buyer receiving eight sealed bids identical to the second decimal point, the Court was skeptical that this could have happened without the eight having been in communication (and "agreement") with one another. Second, the Court remarked that, in part because of the radical departure, there was great risk to any distributor that went along with Interstate's request without some assurance that the other distributors would take the same path. ${ }^{23}$ So while the parallel conduct presented a mystery, for the trial court (and ultimately the Supreme Court), the hypothesis of agreement was the most

\footnotetext{
${ }^{22}$ Interstate Circuit, 306 U.S. at 222 ("There was risk, too, that, without agreement, diversity of action would follow. Compliance with the proposals involved a radical departure from the previous business practices of the industry and a drastic increase in admission prices of most of the subsequent-run theaters.").

${ }^{23}$ Id. ("Each was aware that all were in active competition, and that, without substantially unanimous action with respect to the restrictions for any given territory, there was risk of a substantial loss of the business and goodwill of the subsequent-run and independent exhibitors, but that, with it, there was the prospect of increased profits. There was therefore strong motive for concerted action.").
} 
plausible answer to the mystery. One might imagine the Justice Department's closing argument to the court to have been something along the lines: "How could this possibly have happened unless the distributors had reached some prior agreement?"24

A European case with some similarities to Interstate Circuit is the Dyestuffs case. ${ }^{25}$ In an industry described as an oligopoly, there were a series of near identical, near simultaneous price increases. The circumstances suggested that while there was an element of price leader/price follower in connection with (at least some of) the increases, some of the actions seemed hard to reconcile with simple price leadership or traditional oligopolistic interdependence. The Court did not state unambiguously that there must have been a traditional agreement, stating that a concerted practice did not have to have all of the elements of a contract. Indeed, in parts, the Court seemed almost to echo the Supreme Court's dictum in Interstate Circuit regarding invitation followed by acceptance, ${ }^{26}$ which would not provide a basis to exonerate classic price leadership in an oligopolistic industry.

A case often paired in law school casebooks with Interstate Circuit is Theatre Enterprises because it demonstrates a situation in which parallel conduct has a perfectly innocent

\footnotetext{
${ }^{24}$ A potentially complicating factor was the fact that Interstate had sent identical letters, containing its demands, to each of the eight distributors, and using the "cc:" designation, made each of the eight aware that its competitors were receiving the identical letter. This is a complicating factor because it might provide an alternative explanation for the parallel conduct by eliminating the coincidence and alleviating the risk at least to some extent. However, the letter proved not to be an obstacle to the Supreme Court's finding of an illegal agreement for two reasons. First, the actual terms of the contracts that eventually came into being differed in significant ways from those proposed in Interstate's letter, suggesting that there had to have been some discussions subsequent to the letter. Second, even if the letter provided a complete explanation for the "coincidence," the Court was prepared to find an unlawful conspiracy stemming from the letter itself. "It is elementary that an unlawful conspiracy may be and often is formed without simultaneous action or agreement on the part of the conspirators .... Acceptance by competitors, without previous agreement, of an invitation to participate in a plan, the necessary consequence of which, if carried out, is restraint of interstate commerce, is sufficient to establish an unlawful conspiracy under the Sherman Act." Interstate Circuit, 306 U.S. at 227. Later in this chapter we will discuss what use might be made of the Court's rather sweeping language in the context of parallelism based solely on oligopolistic interdependence.

${ }^{25}$ Imperial Chemical Indus. v. Commission, Case 48/69, E.C.R. 619 (1972).

${ }^{26}$ Id.
} 
explanation. The Crest Theater was a movie theater in suburban Baltimore that approached a number of major film distributors (basically the same cast of characters as those in Interstate Circuit) to be allowed to show "first-run" films. The tradition in the industry, not really challenged in the case, was that only one theater in a metropolitan area such as Baltimore would get any new film; i.e., there was area-wide exclusivity. Each of the distributors rebuffed The Crest in favor of awarding its first-run films to one of the large theaters in downtown Baltimore. The Crest claimed that the parallel conduct was best explained as the result of an agreement among the distributors. When the jury returned a verdict for the distributor defendants, The Crest sought a judgment notwithstanding the verdict, arguing that the trial judge should have directed a verdict for the plaintiff. Here the Court thought that the "coincidence" could easily be explained as the result of each distributor independently reaching the same conclusion; i.e., if it had to choose between licensing a downtown theater and one in suburban Baltimore, the downtown theater was the obvious choice regardless of what the other distributors decided. ${ }^{27}$ Therefore, no prior agreement was needed to explain each distributors conduct. The "coincidence" was the result of each distributor independently reacting to the same basic market forces.

It would appear, therefore, that the framework is complete. There is widespread agreement that simply parallel conduct is not enough to permit an inference of agreement. While parallel conduct can be interdependent and the result of a prior agreement, it can also be rational, independent, "competitive" behavior. Each firm would behave the same way regardless of what it anticipated its competitors might do, and hence no prior agreement is required to explain the

\footnotetext{
${ }^{27}$ Of course, each distributor may have expected the others to act similarly but that was not the result of any prior communication of agreement since each distributor would have rejected The Crest even if it knew that one or more of the others might not. Thus, "regardless" becomes a key word in the defense's dictionary.
} 
parallelism. The task, then, it might seem is simply to determine when parallel conduct is interdependent and when it is independent. The former suggests the presence of an agreement; the latter does not.

\section{Oligopoly Complicates the Analysis/Proof}

Unfortunately, parallel conduct that results from agreement on one hand and parallel independent (and "competitive") conduct on the other are not the only possibilities. Consider the now well-used example of the only two gas stations for miles around (i.e., a separate geographic "market") located right across the road from one another. Assume that, to this point, prices have been parallel (i.e., identical) but competitive, at \$1 per gallon for "regular" gas. ${ }^{28}$ Call the two owners $A$ and $B$, respectively. Owner $A$ begins pondering whether his station can be made more profitable and consults an economist who, after doing some fancy econometric research (and charging appropriately), announces that she has good news. It turns out that market demand for gasoline is highly inelastic. If the market price were to double to $\$ 2$, overall market demand would decrease by less than $50 \%$, and hence overall revenues (and $a$ fortiori profits) for the market as a whole (i.e., both stations) would increase.

But the advice comes with some bad news as well. If A increases price to $\$ 2$, while B keeps its price at $\$ 1$, B will get all the business, rendering B highly profitable, and driving A into bankruptcy. $A$, sensing the risk of increasing price in this situation, contemplates calling $B$ and suggesting they agree to raise price together but is cautioned by his antitrust lawyer that this might mean a hefty fine and a long prison sentence. He is about to show the economist the door (without paying her bill) as having provided accurate but useless information. The economist saves the day, however, by asserting that, even though no direct communication between $A$ and

\footnotetext{
${ }^{28}$ The example is badly dated with respect to the price, but it keeps the numbers easier.
} 
B would be allowed, she is quite certain that, if A initiates a price increase, B will follow promptly and they can continue "sharing" the market at a price of $\$ 2$ and enjoy the supra-normal profits she originally predicted.

When asked how she can be so sure, she responds simply: If you increase price to $\$ 2$, B will be fully aware of what you have done because your prices are fully visible across the street. So if B wants to follow you, he can. And he will want to. Technically there are three possible outcomes: a) both $A$ and $B$ charge $\$ 2 ; b) A$ charges $\$ 2$ and $B$ keeps the price at $\$ 1$; and $c$ ) both $A$ and $B$ charge $\$ 1$. Now I have conceded that option (b) is the best possible outcome for $\mathrm{B}^{29}$ and the worst possible outcome for A. But B knows that option (b) is not a realistic equilibrium. B knows that if he doesn't match A, A will know that almost immediately, and will react by reversing the price increase. B won't get that much business in the time it will take A to react, and the end result, therefore, is that both $A$ and $B$ are stuck at $\$ 1$ for the foreseeable future. Therefore, of the only two realistic scenarios, B's matching A's price increase is clearly preferable for B.

The result then is that $A$ increases price to $\$ 2$ (which can be assumed to be the profitmaximizing market price, the exact price $A$ and $B$ would have agreed to had they met face-toface), B matches A's price, and the $\$ 2$ price remains in effect indefinitely. The $\$ 2$ price is parallel, interdependent (i.e., A would not charge \$2 regardless of what he thought B might do; if he knew that B would not follow, he would keep, his price at \$1) and, by assumption, not competitive. But it is the result not of any formal agreement, but rather of the oligopolistic structure of the market. For future reference we can call the resulting outcome that of "pure oligopoly."

\footnotetext{
${ }^{29}$ I have assumed this to be the case. It would not take very unrealistic assumptions about fixed and variable costs to generate that result.
} 
From the consumer's perspective, the oligopoly price is just as bad as the cartel price. ${ }^{30}$

Therefore, given that we have already determined that Section 1 of the Sherman Act does not require a legally binding contract to make up an "agreement," the natural question is whether the concept of agreement requirement can be stretched to include the pure oligopoly outcome. The language of Interstate Circuit in referring to the letter might be called on here. A's initial posting of the $\$ 2$ price would constitute the "invitation" and B's matching that price would constitute the "acceptance".

However, virtually all courts (and most commentators) that have considered the issue have concluded that "pure" oligopoly pricing does not violate Section 1 even when the result is supracompetitive prices. Typical of courts' analysis is the following passage by then-Judge Stephen Breyer:

Courts have noted that the Sherman Act prohibits agreements, and they have almost uniformly held, at least in the pricing area, that such individual pricing decisions (even when each firm rests its own decision upon its belief that competitors will do the same) do not constitute an unlawful agreement under section 1 of the Sherman Act. That is not because such pricing is desirable (it is not), but because it is close to impossible to devise a judicially enforceable remedy for "interdependent" pricing. ${ }^{31}$

\footnotetext{
${ }^{30}$ To be fair, many standard oligopoly models (such as the Cournot model) compute the oligopoly price as above the competitive level but not quite as high as the pure monopoly (or cartel) price. See John E. Lopatka \& William H. Page, Economic Authority and the Limits of Expertise in Antitrust Cases, 90 CORNELL L. REV. 617 (2005). For purposes of the discussion, however, all that matters is the conclusion that the oligopoly equilibrium price is above the competitive level.

${ }^{31}$ Clamp-All Corp. v. Cast Iron Soil Pipe Inst., 851 F.2d 478, 484 (1st Cir. 1988) (internal citations omitted). I made the same point some 30 years ago, arguing that there is no "culpable" behavior in oligopoly pricing and that a court could not require a firm to pretend that it was not operating in an interdependent environment. George A. Hay, Oligopoly, Shared Monopoly, and Antitrust Law, 67 CORNELL L. REV. 439 (1982).
} 
The European Court of Justice (EJC) has apparently reached the same conclusion. In 1993 the Court, in commenting on a series of parallel price increases, observed that, although the law prohibits collusion, it does not deprive firms of "the right to adapt themselves intelligently to the existing and anticipated conduct of their competitors." ${ }^{32}$ And, even more directly, the Court said that "the parallelism of prices and the price trends may be satisfactorily explained by the oligopolistic tendencies of the market..." ${ }^{33}$

A partial but notable dissent from the above is from Judge Richard Posner, who, early in his career as an academic, advocated applying the Sherman Act to oligopoly pricing, and still believes that the language of the Act is broad enough to encompass such pricing (which he would call a "tacit agreement"). But apparently Judge Posner accepts the proposition that courts have not embraced this possibility (and will not). ${ }^{34}$ More recently, Lewis Kaplow has sought to revive the debate, arguing that oligopoly pricing can and should be covered. ${ }^{35}$

However, assuming no change in the legal status of oligopoly pricing is imminent, a court presented with evidence of parallel behavior (especially pricing) must consider that there are three possible explanations: a) the conduct is parallel but independent and competitive neither harm nor foul; b) the behavior is parallel, interdependent and non-competitive (e.g., prices are at supra-competitive levels), but the result solely of oligopolistic interdependence harm but apparently no foul; c) the behavior is parallel, interdependent, non-competitive and

\footnotetext{
${ }^{32}$ See A.Ahlstrom Osakeyhtio v. Commission (Woodpulp II), Joined Cases C-89/85, C-104/85, C-114/85, C116/85, C-117/85 and C-125/85 to C-129/85, [1993] E.C.R. I-1307, at para. 71.

${ }^{33}$ Id. at para. 126 .

${ }^{34}$ In re High Fructose Corn Syrup Antitrust Litig., 295 F.3d 651, 654 (7th Cir. 2002) ("[The] statutory language [of section 1 of the Sherman Act] is broad enough ... to encompass a purely tacit agreement to fix prices, that is, an agreement made without any actual communication among the parties to the agreement. ... Nevertheless, it is generally believed, and the plaintiffs implicitly accept, that an express, manifested agreement, and thus an agreement involving actual, verbalized communication, must be proved in order for a price-fixing conspiracy to be actionable under the Sherman Act.").

${ }^{35}$ Louis Kaplow, An Economic Approach to Price Fixing, 77 ANTITRUST L.J. 343 (2011).
} 
the result of an agreement - both harm and foul. If the plaintiff has only circumstantial evidence, that evidence must be capable of distinguishing the last explanation (agreement) from either of the first two.

\section{Distinguishing Agreement from Oligopolistic Interdependence}

While the coincidence/risk analysis identified in Interstate Circuit can still provide the framework on which any pattern of circumstantial evidence must be hung, the addition of oligopoly as a complete explanation for supra-competitive pricing complicates the process considerably. Moreover, it is a very abstract and theoretical framework. Subsequent trial and appellate courts have tried to reduce the level of generality one notch by referring to "plus factors" and asserting that, in the absence of direct evidence of an agreement, plaintiffs must, in addition to establishing parallel conduct, identify certain "plus factors" that make the hypothesis of agreement more plausible that any competing hypothesis either parallel, but competitive conduct, of the kind found in Theatre Enterprises, or parallel non-competitive conduct that is the result solely of oligopolistic interdependence.

Unfortunately, although perhaps inevitably, there is no uniformity among courts on what can constitute a plus factor, but there are some commonalities. Perhaps the most common plus factor identified by courts is the structure of the industry. The idea is that certain industry structures are simply not conducive to successful coordination on price. If the industry is unconcentrated, the product is highly differentiated, demand is very elastic, the market is unconcentrated on the buying side, and there are few barriers to entry (other factors could be added as well), then even the most elaborate formal cartel is unlikely to be successful. ${ }^{36}$ If collusion stands little or no chance of success, why would firms expose themselves to the severe

\footnotetext{
${ }^{36}$ George A. Hay \& Daniel Kelley, An Empirical Survey of Price Fixing Conspiracies, 17 J.L \& Econ. 13 (1974). See also High Fructose Corn Syrup, 295 F.3d at 651.
} 
penalties that would flow from detection and prosecution? (The fact that the cartel was unsuccessful would not immunize a cartel from criminal sanctions although it might diminish or eliminate the damages it would be liable for.)

However, while structural factors indicating that the industry is not susceptible to successful collusion may help to eliminate some price fixing claims, factors suggesting that the industry is susceptible to collusion may also be consistent with the possibility that the parallel prices (even if supra-competitive) could be the result of simple oligopolistic interdependence without any explicit agreement. As Judge Posner asserts in High Fructose, the plaintiffs "must present evidence that would enable a reasonable jury to reject the hypothesis that the defendants foreswore price competition without actually agreeing to do so." ${ }^{37}$ Therefore we need to look at some of the other factors identified by courts.

Typical of the approach is the analysis in Blomkest, a case alleging an agreement on price among producers of potash (although it must be pointed out that the court is simply reacting to the list of plus factors provided by the plaintiff). The court refers to three plus factors identified by the plaintiff: (1) interfirm communications between the producers; (2) the producers' acts against self-interest; and (3) econometric models purporting to prove that prices would have been lower in the absence of collusion. ${ }^{38}$ (Elsewhere the dissent also refers to the structural conditions of the industry as not being incompatible with collusion. ${ }^{39}$ )

Considering the factors in reverse order, the third factor in Blomkest (econometric models), seems to be just another way of saying that prices were above the competitive level. If that is the case, such a plus factor serves to rule out the explanation of parallel, but competitive

\footnotetext{
${ }^{37}$ High Fructose Corn Syrup, 295 F.3d at 661.

${ }^{38}$ See Blomkest Fertilizer, Inc. v. Potash Corp. of Saskatchewan,, 203 F.2d 1028 (8th Cir. 2000).

${ }^{39}$ Id. at 1044-51 (Gibson, J., dissenting).
} 
conduct (Theatre Enterprises) but still leaves either collusion or oligopoly as competing explanations. ${ }^{40}$ Therefore it falls in the same category as structural conditions conducive to collusion.

The second factor (producers' acts against self-interest) seems almost an oxymoron, since economists assume that firms always act in their own self-interest. What is meant, however, is that the producers' actions don't make sense unless we assume that there was an agreement in place. This comes close to simply restating the coincidence/risk framework of Interstate. The behavior is too much of a coincidence or too risky for each firm to undertake without some prior understanding that others would do the same. But this factor falls in the same category as the structural and economic evidence unless the plaintiff can make the case that the necessary "understanding" is not simply a tacit understanding deriving solely from oligopolistic interdependence. This is where Interstate Circuit provides a nice model. In upholding the trial court's finding of an (explicit) agreement, the Supreme Court determined in effect that the change in contracting was so radical and so risky (and differed from the initial proposal circulated by Interstate via the infamous letter) that simple oligopolistic interdependence could not explain it. There must have been some explicit communications. ${ }^{41}$

Turning back to price fixing cases, we can supplement our discussion of structural factors to make some good use of the concept of actions against self-interest. There may be some oligopoly situations where many of the structural conditions may be susceptible both to explicit

\footnotetext{
${ }^{40}$ It is hard to say too much more about this factor because the court rejected the expert report that underlay the factor. It is conceivable (although unlikely in this case) that the plaintiff meant that prices were not only above the competitive level, but above the oligopoly level as well, assuming that the underlying oligopoly model predicts a price that is less than the monopoly or cartel price. This distinction will be discussed further when we get to "actions against self-interest."

${ }^{41}$ Of course, as mentioned above, the Court also determined that if the letter were enough to explain the parallel actions of the defendants, the letter (as an invitation) followed by acceptance would constitute an unlawful conspiracy. See supra notes 20-21 and accompanying text. See also Interstate Circuit, Inc. v. United States, 306 U.S. 208 (1939).
} 
collusion and to oligopolistic interdependence leading to supra-competitive prices, such as high concentration, inelastic demand, lack of concentration on the buying side, high barriers to entry, etc., but other structural factors may be more problematical. For example, if prices are not transparent (i.e., each competitor's prices cannot, in the normal course, be observed by other competitors), this makes both arriving at an initial consensus on price (through price leadership, for example) and monitoring adherence to any supra-competitive price very difficult without formal communication and explicit agreement. Therefore if we observe each firm charging supra-competitive prices, we might conclude that it would not be in any one firm's interest to have done so with some prior assurance that others would do the same, and that the structural conditions make it difficult/impossible for that assurance to have evolved simply from oligopolistic interdependence.

This provides a nice segue to the final plus factor identified in Blomkest (the first one listed by the court) - interfirm communications. ${ }^{42}$ There was evidence that firms were engaged in the practice of price verification. This typically occurs when a customer reports to its usual supplier that a competing supplier has offered an unusually low price (in circumstances where actual sales prices are typically not a matter of public record). The usual supplier then contacts the competitor, reports the customer's assertion, and asks if the assertion is correct. The custom is for the competitor to be truthful in revealing whether the customer's assertion is accurate. The majority of the appellate panel had difficulty understanding how a discussion of past prices could possibly lead to any agreement as to prices to be charged in the future, in part perhaps

\footnotetext{
${ }^{42}$ Some interfirm communications may be circumstantial evidence in the most fundamental sense; i.e., while we do not have a video recording of the actual cartel meeting, there is enough evidence of communication (in circumstances where there is no obvious legitimate reason for communications between or among executives) to suggest that the parties were in fact discussing the prices to be charged. This would be similar in kind to evidence that key executives were all staying at the same hotel at the same time without an obvious explanation such as a trade association meeting. The discussion in the text has a different focus.
} 
because the majority thought that the essential function of any cartel is to achieve some kind of consensus on prices to be charged. If there are differences of opinion as to the correct "cartel price," these need to be worked out through some kind of direct communication.

The dissent, however, identified a second critical function of any cartel, viz., to monitor, detect, and discourage deviations from any consensus price. In that light, the price verification functions as a convenient tool. If a firm knows that its "cheating" will be detected (and presumably matched), there is less incentive to cheat in the first place. The fact that firms were engaged in price verification is taken as evidence that there must have been some underlying agreement on price, and that the verification served to support that agreement. Otherwise why would firms reveal sensitive information about their own transactions? If a firm really wanted to get more business away from its competitors by secretly offering discounts to customers, revealing its actual prices would throw away any advantage it might have helped to secure. Thus, these kinds of interfirm communications would be against the self-interest of the producers unless there was an agreement in place that firms would generally try to adhere to a supra-competitive price.

\section{Facilitating Practices}

Some courts have described practices such as interfirm communications "facilitating practices." And in some of these cases, it is merely a label change. An example is then-Judge Sotomayor's opinion in Todd v. Exxon, which also involved an exchange of pricing information. The court describes information exchange "as an example of a facilitating practice that can help support an inference of a price-fixing agreement." ${ }^{43}$ The basic claim is that there was an actual agreement (on price). The so-called facilitating practice is relevant as evidence of this underlying

\footnotetext{
${ }^{43}$ Todd v. Exxon Corp., 275 F.3d 191, 198 (2d Cir. 2001). .
} 
agreement in the sense that engaging in the practice would not make sense absent the underlying agreement. ${ }^{44}$

In other cases invoking the facilitating practices label, the approach seems to be somewhat different. Imagine the following scenario somewhat like the potash industry in Blomkest: an industry is oligopolistically structured and almost all the related structural factors are supportive either of a formal cartel or of supra-competitive prices achieved merely through oligopolistic interdependence. But there is one factor that stands in the way of success merely through oligopolistic interdependence. Suppose for example that one competitor's prices cannot be directly observed by another, but can be identified only (usually thought customer contacts) after the passage of some time. This creates a risk for any firm seeking to implement a price increase. Because the initiator of the price increase knows that its price cannot be directly observed, it has little confidence (even if it was confident that others would want to follow) that rivals will be able follow it at least for some period of time, during which the initiator may stand to lose a lot of business. ${ }^{45}$

In response to the uncertainty, the firms may adopt practices that reduce it. The most obvious, and legally easiest to deal with, is where the firms agree to exchange certain information, such as the information about recent transactions described above as price verification, that allows competitors to determine whether rivals have been secretly engaged in price discounting. Earlier, the price verification was presented as circumstantial evidence of an underlying

\footnotetext{
${ }^{44}$ I have written extensively about the theory of facilitating practices and efforts to implement it. See, e.g., Facilitating Practices, infra note 49; George A. Hay, Facilitating Practices, in ISSUES IN COMPETITION LAW AND Policy 1189 (Collins ed. 2008); George A. Hay, Horizontal Agreements: Concept and Proof, 51 The Antitrust Bulletin 877 (2006); and George A. Hay, The Meaning of "Agreement" Under the Sherman Act: Thoughts from the "Facilitating Practices" Experience, 16 REV. INDUS. ORG. 113 (2000).

${ }^{45}$ The lack of price transparency also complicates the problem of cheating and that may have to be dealt with through other facilitating practices, such as most favored nations' clauses, as discussed below in the text following note 49.
} 
agreement. An alternative approach is to attack the agreement to exchange information as an agreement that is unlawful because it leads to a substantial lessening of price competition without a formal agreement once the uncertainty about rivals' cooperation has been eliminated. Thus, the facilitating practice in effect becomes the violation. But what makes this approach work without clashing with the traditional hands-off approach to oligopolistic conduct is that there was an agreement to exchange the information or otherwise to engage in the "facilitating practice, " that can fit comfortably with traditional interpretations of Section $1^{46}$ or Article $101^{47}$ as outlawing agreements that restrict or distort competition.

A more challenging problem is when it cannot be demonstrated that the facilitating practice was adopted via any agreement. So assume, for example, that a firm (and its competitors) without prior agreement to do so, adopt the practice of publicly announcing price increases that will not become effective for, say, 30 days. ("Effective in 30 days, I plan to increase price by $10 \%$ to $\$ 300$ per unit.") This substantially eliminates the risk that rivals will be unable to follow if they would otherwise want to. The rivals are made aware of the proposed price increase and have up to 30 days to signal, by a similar announcement (without the lead time) that they plan to follow. Meanwhile, the initiator is not at risk of losing sales since, for the time being, its price is no higher than any of its rivals. If rivals don't announce their intention to follow within the 30 day

\footnotetext{
${ }^{46}$ Todd v. Exxon Corp., 275 F.3d 191 (2d Cir. 2001). The opinion, discussed supra note 43, also indicates that a completely different way to package the information exchange is to focus on the agreement to exchange information as the illegal agreement rather than as circumstantial evidence of an agreement to fix prices. Id. at 198. An agreement to exchange information will normally be easier to establish but the downside, as Judge Sotomayor points out, is that such agreements are generally treated under the rule of reason, so the plaintiff retains the burden (which is circumvented in per se cases) of showing that the agreement actually had an adverse effect on competition. Id. at 198-99. There is a whole line of Supreme Court cases, starting with United States v. Container Corp., 393 U.S. 333 (1969), that focus on the agreement to exchange information as the target of inquiry.

${ }^{47}$ The agreement to exchange information would be covered by the EU's 'Guidelines on the applicability of Article 101 of the Treaty on the Functioning of the European Union to horizontal co-operation agreements," 2011, available at http://eurlex.europa.eu/LexUriServ/LexUriServ.do?uri=OJ:C:2011:011:0001:0072:EN:PDF.
} 
window, the initiator simply withdraws the increase. Since the rivals know this will happen, they have every incentive to follow the increase without the need for any direct communication. So now, by plus factor we mean "oligopoly plus" in the sense that we do not believe that any direct communication was necessary for the oligopoly to achieve and sustain supra-competitive prices. The facilitating practice (the advance public announcement) was sufficient to do the trick. ${ }^{48}$ If that is the explanation, the legal analysis changes. Instead of saying that the practice is circumstantial evidence of a traditional agreement, the argument is that the parallel supracompetitive prices, combined with the use of the facilitating practices, establish an illegal agreement (even if a tacit one). We do not believe (and are not trying to prove) that there was any formal hotel room conspiracy because we believe that the facilitating practices made such a meeting unnecessary. The legal question is whether a court that would reject pure oligopolistic interdependence as constituting an actionable agreement could nevertheless find that oligopolistic interdependence (intentionally) facilitated by certain specific practices forfeits the safe haven for pure oligopolistic interdependence (because now we have intentional, and therefore culpable, conduct). ${ }^{49}$

Advance public announcements of "proposed" price increases is perhaps the most commonly identified facilitating practice. Another prominent one, also featured in the Ethyl case, was providing customers with a most-favored-nations clause (MFN). This can be useful if one obstacle to achieving a supra-competitive price without any formal communication is each

\footnotetext{
${ }^{48}$ As suggested supra note 46 , I don't claim that simply the announcement will necessarily bring about a supra-competitive equilibrium without direct communication, but simply that it could, either singly or in conjunction with other facilitating practices.

${ }^{49}$ If the practices were not initiated for the purposes of facilitating oligopolistic interdependence but come to have that effect, the analysis might be different. This was one of the principal problems confronting the FTC in the Ethyl case. See Ethyl Corp. v. Federal Trade Commission, 729 F.2d 128 (1984); George A. Hay, Facilitating Practices: The Ethyl Case (1984), in The ANTITRust ReVolution: EConomics, COMPETITION AND PoliCY 182 (John E. Kwoka, Jr. \& Lawrence J. White eds., 3d ed. 1999). Other problems with the FTC's theory in Ethyl are discussed below.
} 
competitor's fear that another will secretly discount price below the "public" (supra-competitive price). This can trigger pre-emptive price cutting by firms who otherwise might be willing to enjoy the oligopolistic equilibrium. Therefore, each firm (or at least each of the major firms) may wish to find a way to convince its competitors that it will not be initiating a discount. The MFN clause promises each customer that, if another customer gets a discount, that customer will be guaranteed the same discount (perhaps even retroactively). ${ }^{50}$ This in turn creates a disincentive for the firm to offer a price cut to a single customer to pick up some incremental business because the price cut must be passed on to other customers who might have been prepared to pay the "public" price. If the firm's rivals are aware that the form has an MFN, this might provide the needed assurance that permits a stable (non-collusive) supra-competitive oligopolistic equilibrium.

In all the above examples, it is assumed that there was no agreement to adopt the facilitating practices (even if rivals subsequently but independently) behave similarly. Therefore the possibility of focusing on an agreement to do so, either under Section 1 or Article 101, is not available. Hence the claim is that the use (without prior agreement) of a practice that facilitates a supra-competitive oligopolistic equilibrium, taken as a package, constitutes an unlawful agreement on price. Such an approach has neither been endorsed (nor rejected) by the U.S. Supreme Court. Two of the most prominent efforts resulted in settlements prior to any litigated judgment. ${ }^{51}$ The FTC's effort in Ethyl was rejected by the Court of Appeals for the Second Circuit,

\footnotetext{
${ }^{50}$ There might also have to be some mechanism made available for customers to monitor a firm's pricing to be sure that no one else has received a better price. Both the MFN and the monitoring provisions were involved in the DOJ's case against General Electric and Westinghouse. See United States v. General Electric Co., (1977-1) Trade Cas. (CCH) 712 (1977).

${ }^{51}$ See id.; see also In re Domestic Air Transportation Antitrust Litig., DC NGa no. 1:90-CV-2484 MHS \& MDL no. 861 (1992).
} 
52 although it was in part the result of other evidentiary problems with the FTC's case rather than a complete rejection of the theory. ${ }^{53}$ While at least one U.S. appellate court seems to have embraced the theory, ${ }^{54}$ it remains an "experimental" treatment.

\section{Conclusion}

The trend towards convergence of substantive antitrust doctrine means that most jurisdictions now condemn agreements among competitors that fix prices. But that same convergence means that those same jurisdictions must wrestle with the problem of how to establish the existence of an agreement, especially in an oligopolistic industry where high prices could, at least in theory, be the result simply of oligopolistic interdependence. Do we condemn such interdependence? Do we ignore it and require an explicit agreement? Or is there some middle ground? This chapter has explored how the U.S. and, to a lesser extent, the EU, have approached the problem of dealing with a cartel when there is no hard evidence of an explicit agreement. The first option is to try to prove the existence of an explicit agreement through circumstantial evidence; a second is to relax somewhat the requirement that there be an explicit agreement. The effort to find the perfect solution continues.

\footnotetext{
${ }^{52}$ See Ethyl, 729 F.2d at 128 . Technically Ethyl did not involve an allegation of agreement since it was brought under Section 5 of the FTC Act, but the Second Circuit's opinion could create problems for the use of a facilitating practices theory under traditional Section 1 allegations.

${ }^{53}$ In addition to the possibility that the practices had legitimate business justifications, as discussed supra note 51, the Court noted the existence of some non-trivial amount of discounting as well as non-price competition, so that there was not a complete elimination of competition. The Court also had doubts about whether, even if there was an absence of vigorous competition, how much of that could be attributed to the facilitating practices as opposed to the basic oligopolistic structure.

${ }^{54}$ See In re Coordinated Pretrial Proceedings in Petroleum Products Litig., 906 F.2d 432, 446 (9th Cir. 1990) ("[a]lthough ... .mere proof of interdependent pricing, standing alone, may not serve as proof of an antitrust violation, we believe that the evidence concerning the purpose and effect of price announcements, when considered together with the evidence concerning the parallel pattern of price restorations, is sufficient to support a reasonable and permissible inference of an agreement, whether express or tacit, to raise or stabilize prices").
} 